\title{
DO YOU HAVE TO BE SMART TO KNOW WHAT THE OTHERS ARE THINKING?
}

\author{
Vladimíra ČAVOJOVÁ, Eva BALLOVÁ MIKUŠKOVÁ, Róbert HANÁK \\ Institute of Experimental Psychology, Slovak Academy of Sciences \\ Dúbravská cesta 9,813 64 Bratislava, Slovak Republic \\ E-mail: vladimira.cavojova@savba.sk
}

\begin{abstract}
Research concerning mindreading has dealt extensively with its (in)dependence on executive functions. However, surprisingly few studies focused on direct relationship of mindreading with intelligence, although it has been proposed that high level mindreading in older children and adults is dependent on general cognitive skills. In the study reported here, two advanced mindreading tests were employed and data about participants' verbal abilities were obtained. There was no significant correlation of verbal ability and memory with any of the mindreading tasks. Our results demonstrate a lack of significant linear relationship of mindreading with the intelligence domains, language and memory as well as support the argument that mindreading exists as a specific independent cognitive domain.
\end{abstract}

Key words: mindreading, general cognitive abilities, verbal abilities, preadolescents

Among the basic mental states we need to explain or predict are beliefs and desires (Doherty, 2009). If I want to be friends with my colleague and I believe that buying him a beer will ensure such (at least temporarily) friendship, I will offer to buy him a beer. The prediction and explaining of people's behavior based on beliefs and desires is known as the Theory of Mind (Doherty, 2009) or Mindreading (Apperly, 2010).

The development of mindreading is related to the development of executive functioning

Acknowledgement: This research was supported by the grant from the Scientific Agency of Ministry of Education VEGA No. 2/0204/09 "Rationality of emotions and quality of reasoning in situation of social exchange". The authors would like to thank especially Zuzana Sapietová for cooperation in the research and collection of the data. (a set of processes that monitor, control, and supervise both thought and action). The link between mindreading and executive functioning is well-established (Doherty, 2009; Perner, Lang, 1990), at least among young children developing their mindreading skills. The mental manipulation with inner states of other people is cognitively demanding and, according to some theories, it represented evolutionary pressure for development of social intelligence (Humphrey, 1976; Whiten, Byrne, 1997). Therefore, it seems quite surprising that mindreading was not examined in relation with intelligence. Verbal ability and memory are usually taken only as confounding factors that are controlled for in studies.

The few studies that examined direct relationship of verbal ability with mindreading failed to find any consistent results. For instance, a study by Rasmusen et al. (2009) of

DOI: $10.21909 / \mathrm{sp} .2013 .01 .621$ 
children with alcohol fetal syndrome and a normal group found no correlations between verbal ability and mindreading tasks. On the other hand, a study by Buitelaar et al. (1999) with children of autistic spectrum disorders indicated that verbal memory, performance IQ, age and gender were the best predictors of social cognitive ability. Pelicano (2007) found significant correlations between most scores on cognitive measures and age, verbal ability, and nonverbal ability, for both autistic and typically developing groups.

Apperly (2011) proposed that throughout the lifespan mindreading is subserved by two distinct systems, low-level (implicit, effortless, and independent of the development of language and executive skills) and laterdeveloping, high-level system (dependent on domain-general cognitive functions, conscious, explicit, inferences about mental states). He builds on a dual system approach in cognitive processing and expands upon the evidence for two systems for mindreading. This dual system approach explains many discrepancies found in mindreading research. However, Schneider et al. (2012) found that implicit mindreading is at least partly dependent on cognitive load. It is, therefore, even more surprising that so far only few studies have examined the direct relationship between mindreading and general cognitive abilities.

In summary, research concerning individual differences in mindreading ability in older, typically developing children with respect to verbal intelligence is still largely missing. Much research concerning mindreading deals with its (in)dependence on executive functions, and few studies have focused on a direct relationship of mindreading with intelligence (Rajkumar et al., 2008).
The rationale behind this paper is twofold: The first aim was to investigate the effect of general cognitive abilities, such as verbal intelligence and memory, on mindreading of pre-adolescents without any disorders. Second, we examined high-level explicit mindreading skills. According to Apperly (2011), these should be heavily dependent on general cognitive abilities (verbal abilities and memory). We assumed that higher verbal abilities would enable preadolescents to elaborate more on the mental states of the presented characters in mindreading tasks.

\section{METHOD}

\section{Participants and Procedure}

Our sample consisted of 47 preadolescents (19 boys and 28 girls) from one public elementary school. Participants' age ranged from 13 to 15 years $(M=13.76, S D=.35)$.

\section{Measures}

1. Imposing Memory Task: IMT (Kinderman, Dunbar, Bentall, 1998) featured a series of five stories that involved complex social situations that required listeners to understand various intentions and perspectives of actors. Children answered questions presented in a booklet and they had to choose between two alternative options, a correct and incorrect one. Questions either concerned mindreading elements in the stories (the expectations or beliefs of participants) or were memory questions. Both types of questions involved a number of levels of complexity. The scores could range from 0 (low level of mindreading abilities) to 40 (high level of mindreading abilities). 
2. Awkward Moments Test: AMT (Heavey et al., 2000) features six short films (characters in awkward or socially embarrassing situations), with three questions after each film: 1) control question (memory and attention to details of the story), 2) emotion question (recognition of the target character's emotion) - there was only one correct answer for which the participant could score 1 point (up to a maximum of 5 points), and 3 ) mindreading question (inferring the intention of the character). Answers to this question were analyzed according to their quality and elaborateness and the total score could range between 0 (poor mindreading skills) and 15 (excellent mindreading skills).

The detailed characteristics of this test and its Slovak adaptation are reported elsewhere (Ballová Mikušková, in press).

3. Intelligence Structure Analysis test (Fay, Trost, Gittler, 2001) is based on preceding classical intelligence tests (IST-70) and on the concept of measuring intelligence structure rather than the overall score. It enables the evaluation of the level of cognitive skills in each group (subtest), as well as overall report about the intellectual skills of an individual. It consists of 9 sets of tasks: 1) Completion of Sentences (verbal-logical thinking, abstraction in verbal expression), 2) Common Features (ability of abstraction in verbal expression), 3) Figural Memory (immediate memory skills), 4) Numerical Sequences (inductive thinking, mental flexibility), 5) Relationships (ability of precise use of verbal terms), 6) Cube Recognition (spatial imagination), 7) Practical Arithmetic (counting, inferences and induction), 8) Generation of Terms (significant aspect of language acquisition), 9) Completion of Figures (concrete imagination). For the purpose of this study, we obtained the scores for the verbal subtests Common Features, Relationships, Generation of Terms, and Memory. Raw scores were used for correlational analyses, as they were not adjusted for age and therefore estimated verbal and nonverbal ability rather than IQ.

\section{RESULTS}

\section{Descriptive Statistics}

Means and standard deviations for all variables in the total sample and for boys and girls separately are presented in Table 1.

There were no significant differences between boys and girls besides a higher score of girls in recognizing relationships (in verbal abilities subtests). Therefore, we conducted further analysis on the whole sample.

\section{Bivariate Correlations}

There was no significant correlation of verbal ability and memory with any of the mindreading tasks. We found only one correlation between mindreading task (AMT) and age $(\mathrm{r}=-.334 ; \mathrm{p}=.043)$.

\section{Linear Regression}

The multiple linear regression (stepwise) with mindreading tasks (IMT, AMT), in either case as a dependent variable, also demonstrated a lack of significant relationship between mindreading and general cognitive abilities. Only age significantly predicted performance in mindreading task (AMT); and the Relationships subtest predicted performance in mindreading task in IMT (Table 2a, 2b). 
Table 1. Means and standard deviations of main study variables in the overall sample and by gender

\begin{tabular}{|c|c|c|c|c|c|c|c|}
\hline & \multicolumn{2}{|c|}{ Overall $(n=47)$} & \multicolumn{2}{|c|}{ Boys $(\mathrm{n}=19)$} & \multicolumn{2}{|c|}{ Girls $(\mathrm{n}=28)$} \\
\hline & & M & SD & M & SD & M & SD \\
\hline \multirow{4}{*}{$\begin{array}{l}\text { Verbal } \\
\text { abilities }\end{array}$} & $\begin{array}{l}\text { ISA Common } \\
\text { Features }\end{array}$ & 49.23 & 22.278 & 47.42 & 17.967 & 50.46 & 25.030 \\
\hline & ISA Relationships & 66.85 & 28.227 & 55.32 & 28.107 & $74.68^{*}$ & 25.954 \\
\hline & $\begin{array}{l}\text { ISA Generation } \\
\text { of Terms }\end{array}$ & 61.89 & 32.746 & 53.21 & 31.687 & 67.79 & 32.686 \\
\hline & ISA Memory & 59.72 & 29.281 & 53.21 & 28.656 & 64.14 & 29.380 \\
\hline \multirow{4}{*}{ Mindreading } & $\begin{array}{l}\text { AMT (emotion } \\
\text { question) }\end{array}$ & 4.77 & .872 & 4.50 & 1.317 & 4.96 & .209 \\
\hline & $\begin{array}{l}\text { AMT (intention } \\
\text { question) }\end{array}$ & 9.00 & 2.790 & 8.06 & 2.792 & 9.68 & 2.644 \\
\hline & IMT (memory) & 21.41 & 1.802 & 20.94 & 1.806 & 21.74 & 1.764 \\
\hline & $\begin{array}{l}\text { IMT } \\
\text { (mindreading) }\end{array}$ & 13.10 & 1.667 & 13.38 & 1.668 & 12.91 & 1.676 \\
\hline
\end{tabular}

Legend: * Means were significantly different by gender; M - mean, SD - standard deviation

Table 2a. Linear regression with AMT mindreading task as a dependent variable

\begin{tabular}{|l|c|c|c|c|c|}
\hline \multirow{2}{*}{ Model } & \multicolumn{2}{|c|}{$\begin{array}{c}\text { Unstandardized } \\
\text { Coefficients }\end{array}$} & $\begin{array}{c}\text { Standardized } \\
\text { Coefficients }\end{array}$ & \multirow{2}{*}{ S } & Sig. \\
\cline { 2 - 4 } & $\mathrm{B}$ & Std. Error & Beta & $\mathrm{t}$ & .014 \\
\hline constant & 47.176 & 18.243 & & 2.586 & .043 \\
\hline age & -2.792 & 1.331 & -.334 & -2.098 & .048 \\
\hline
\end{tabular}

Table $2 \mathrm{~b}$. Linear regression with IMT mindreading task as a dependent variable

\begin{tabular}{|l|c|c|c|c|c|}
\hline & \multicolumn{2}{|c|}{$\begin{array}{c}\text { Unstandardized } \\
\text { Coefficients }\end{array}$} & $\begin{array}{c}\text { Standard. } \\
\text { Coefficients }\end{array}$ & & \\
\cline { 2 - 4 } Model & $\mathrm{B}$ & Std. Error & Beta & $\mathrm{t}$ & Sig. \\
\hline constant & 11.894 & .653 & & 18.220 & .000 \\
\hline $\begin{array}{l}\text { ISA } \\
\text { Relationships }\end{array}$ & .018 & .009 & .320 & 2.028 & .050 \\
\hline
\end{tabular}




\section{DISCUSSIONAND CONCLUSION}

Our study had two aims - to explore the relationship between general cognitive skills and mindreading in older children (with established mindreading skills) without any disorders (sufficient mindreading skills) and to explore this link in the context of Apperly's (2011) dual system approach to mindreading. High-level mindreading, as tested by advanced mindreading tests placing relatively high demands on quick understanding of stories and memory, was therefore expected to be dependent on general cognitive abilities. However, our results are more in line with findings of Rajkumar et al. (2008) and demonstrate a lack of significant linear relationship of mindreading with the verbal abilities and memory, as well as support the argument that mindreading exists as a specific independent cognitive domain.

It seems that factors other than intelligence per se are responsible for individual differences in mindreading beyond the age of acquiring the theory of mind. We assumed that higher verbal abilities could play a role in the elaboration of mental states of other persons, but this was not the case. These results could have been caused also by the fact, that one of the mindreading tests was in a multiple choice format (with no place for elaboration) and in the other one children also wrote as little explanations as possible (for more detailed analysis see Ballová Mikušková, in press).

The only results found were that Relationships (ISA) predicted performance in written Mindreading Task (IMT) and age predicted performance in video Mindreading Task (AMT). Partial connection between the ability to detect relationships between words and between characters in the short written account can reflect good semantic understanding and be an artefact of the test format. On the other hand, association of age and better performance in mindreading tests is quite straightforward and was demonstrated in some of our other work (Mentel, Čavojová, unpublished manuscript), as well of other studies (e.g., Doherty, 2009). It also suggests the need for further examination of individual differences in mindreading beyond the age of acquiring the Theory of Mind.

We are aware that the small size of the sample does not allow for generalizations, but the surprising lack of examination of associations of mindreading and general cognitive skills led us to test some of our assumptions on this small subsample of a larger study. Few existing findings so far point out the lack of significant relationships between mindreading and general cognitive abilities. However, given the usual verbal formats of tests, the question whether general cognitive abilities, and especially verbal abilities, account to some degree for specialized cognitive domains, such as mindreading, is still worth studying. For now, it is fair to say that you do not need to be particularly bright to know, whether it is worth buying someone a beer or not. (It usually always is.)

Received August 21, 2012

\section{REFERENCES}

APPERLY, I., 2011, Mindreaders. The cognitive basis of "Theory of Mind". Hove: Psychology Press. BALLOVÁ MIKUŠKOVÁ, E., (in press), Adaptation procedure of Awkward Moments Test for Slovak population. Studia Psychologica.

BUITELAAR, J.K., VAN DER WEES, M., SWAAB-BARNEVELD, H., VAN DER GAAG, R.J., 1999, Verbal memory and performance IQ predict Theory of Mind and emotion recognition ability in children with autistic spectrum disorders and in psy- 
chiatric control children. Journal of Child Psychology and Psychiatry, 40, 6, 869-881.

DOHERTY, M.J., 2009, Theory of Mind: How children understand others' thoughts and feelings. Hove: Psychology Press.

FAY, E., TROST, G., GITTLER, G., 2001, T309. Analýza štruktúry inteligencie - ISA. Upr. T. Kováč. Bratislava: Psychodiagnostika, a.s.

HEAVEY, L., PHILLIPS, W., BARON-COHEN, S., RUTTER, M., 2000, The Awkward Moments Test: A naturalistic measure of social understanding in autism. Journal of Autism and Developmental Disorders, 30, 225-236.

HUMPHREY, N.K., 1976, The social function of intellect. In: P.P.G. Bateson, R.A. Hinde (Eds.), Growing points in ethology (pp. 303-317). Cambridge: Cambridge University Press.

KINDERMAN, P., DUNBAR, R., BENTALL, R.P., 1998, Theory-of-mind deficits and causal attributions. British Journal of Psychology, 89, 191 204.

MENTEL, A., ČAVOJOVÁ, V., unpublished manuscript, Item analysis of Imposing Memory Test.

PELLICANO, E., 2007, Links between theory of mind and executive function in young children with autism: Clues to developmental primacy. Developmental Psychology, 43, 4, 974-990.

PERNER, J., LANG, B., 1990, Development of theory of mind and executive control. Trends in Cognitive Science, 3, 337-44.

RAJKUMAR, A.P., YOVAN, S., RAVEENDRAN, A.L., RUSSEL, P.S.S., 2008, Can only intelligent children do mindreading: The relationship between intelligence and theory of mind in 8 to 11 years old. Behavioral and Brain Function, 4, 51, $1-7$.

RASMUSSEN, C., WYPER, K., TALWAR, V., 2009, The relation between theory of mind and executive functions in children with fetal alcohol spectrum disorders. Canadian Journal of Clinical Pharmacology, 16, 2, 37-380.

SCHNEIDER, D., LAM, R., BAYLISS, A.P., DUX, P.E., 2012, Cognitive load disrupts implicit Theory-of-Mind processing. Psychological Science, $X X(X), 1-6$. Psychological Science OnlineFirst, published on July 3, 2012 as doi:10.1177/ 0956797612439070.

WHITEN, W., BYRNE, R.W., 1997, Machiavellian intelligence II: Extensions and evaluations. Cambridge: Cambridge University Press.

\title{
MUSÍTE BYŤ DÔVTIPNÝ, ABY STE VEDELIČO SI INÍ MYSLIA?
}

\author{
V. Čavojová, E. B a 11 ová Mikušková, R. H a nák
}

Súhrn: Hoci sa všeobecne predpokladá, že vyššia úroveň schopností chápania mysle u starších detí a dospelých je závislá od všeobecných kognitívnych schopností, doteraz len málo výskumov skúmalo vzt’ah medzi chápaním duševných stavov a inteligenciou priamo. Ciel’om príspevku je preto predstavit' predbežné výsledky z pilotného výskumu vztahu verbálnej inteligencie a pamäte s chápaním duševných stavov u preadolescentov. Vo výskume boli použité dva testy chápania mysle (IMT, Kinderman et al., 1998; AMT, Heavey et al., 2000) a získali sa dáta o verbálnych schopnostiach participantov zo štandardného testu inteligencie (ISA, Fay et al., 2001). Nenašiel sa žiadny signifikantný vzt’ah verbálnych schopností a pamäte so žiadnou z úloh na chápanie duševných stavov. Výsledky poukazujú na absenciu lineárneho vzt’ahu chápania duševných stavov s inteligenciou, verbálnymi schopnost'ami a pamätou, a tiež podporujú argument, že chápanie duševných stavov predstavuje špecifickú nezávislú kognitívnu doménu. 